\title{
Navy lifts veil on PWR research
}

The PWR is not new to Britain.

\section{David Fishlock describes Rolls Royce's experience}

in developing the reactors for the Navy

H MS SCEPTRE, Britain's 14th take a name not already made famous as a capital ship-was commissioned by the Royal Navy last month. The event coincided with a decision to lift the veil slightly on an $R \& D$ programme which has remained secret for nearly two decades.

The peaceful application of the technology which has transformed the submarine from a submersible of strictly limited endurance into an underwater fighting ship has long been a matter of serious discussion. Several factors have inhibited progress. Costs of marine nuclear-propulsion-systems have remained high enough to limit interest to very large vessels or special-purpose craft such as icebreakers, submarine oil transports, or submersibles for seabed construction projects. The world has also been slow to develop universally acceptable safety criteria for seagoing nuclear steam-supply-systems that would allow nuclear vessels to steam freely and gain ready access to ports.

A third factor has been the military origins of much of the development of marine reactors, and the difficulty of separating a civil product from a highly classified technology. This has been an important factor in Britain, where the submarine reactor programme has its origins in an AngloUS treaty signed in 1958. Under its terms the US Navy provided Britain with technology to advance the Ministry of Defence's embryonic project at Harwell by several years. Britain procured a reactor from Westinghouse Electric for HMS Dreadnought, its first nuclear submarine, and also received a "technology transfer" relating to the Dreadnought PWR technology at that time.

But a new factor has recently asserted itself. The electricity supply industry has persuaded the government that it still has enough worries about the thermal reactor system on which its nuclear construction programme depends, namely the advanced gascooled reactor, to justify pursuing an alternative system. This is the Westinghouse pressurised water reactor (PWR), developed from the company's submarine reactor to a thermal megawatt output about 40 times as great. Rolls-Royce, the company chosen to manage the Navy's submarine reactor programme, believes that it has technology and experience which could be valuable in developing a 'British PWR' for electricity generation, as well as surface vessels such as the icebreaker Canada is proposing to cleave through $10 \mathrm{ft}$-thick sheets of ice.

Vice-Admiral Hyman G. Rickover, responsible then (and still) for the US Navy's nuclear fieet, had asked that Rolls-Royce should be the company to manage the procurement and technology transfer for Britain. He chose it because its engineering and quality assurance standards were closest to those he had found essential for the success of the highly sophisticated nuclear engine. Techniques for programme management, planning, and financial control were more backward in Britain in the late $1950 \mathrm{~s}$, but the Westinghouse/Navy methods were all part of the technology package the US was willing to transfer.

\section{Britain's first PWR}

To receive it, the Ministry of Defence encouraged the establishment of an industrial consortium called RollsRoyce and Associates, comprising $54.1 \%$ Rolls-Royce, with Babcock and Wilcox (which came in in 1967), Foster Wheeler and Vickers each having $15.3 \%$. Its initial tasks were to arrange for the procurement of a US-built nuclear steam supply system (NSSS), the Westinghouse S5W PWR, for Dreadnought; and the accompanying technology transfer that would enable it to complete the design and assemble Britain's first PWR. This was built on the north coast of Scotland, adjoining the site of the Dounreay Fast Reactor experiment. It was incorporated into about 2,000 tons of submarine, constructed by Vickers, including the entire propulsion system of a nuclear submarine. (Steam propulsion, it may be recalled, was then something new to submariners.) Later named HMS Vulcan-.. after the lame god who never fought-the half-submarine operated as a prototype NSSS, and also as a development and training facility where new concepts could be tried out, or operational troubles simulated. This British PWR has been running since 1965, during which time it has been extensively modified in two major refits to adapt it to developments from the design and development department of Rolls-Royce and Associates.

From an initial team of 200 , the company has grown to 1,300 today. It has provided the Navy with 16 PWRs and 30 cores. As it learned from Westinghouse and then won the confidence of the Navy, the Ministry of Defence delegated to it more and more responsibility. "We taught ourselves the fundamental technology that was not part of the package the government bought from Westinghouse," says Peter Goodwin, its managing director. Since 1965 it has managed HMS Vulcan for the Ministry of Defence under the direction of a Captain Superintendent who has responsibility for health and safety at the facility. Thus it is the only private company in Britain operating a power reactor. About 300 of its staff are based at HMS Vulcan.

All but a handful of the other 1,000 staff are based at Derby, and about 450 of them are engaged in research, development and design. The Ministry of Defence has delegated to the company the design authority for the NSSS "from cradle to grave", says Peter Jones, the director responsible. But he works closely with the Navy's Ship Department at Bath; with HMS Vulcan (managed by a fellow director); and with Harwell. The company's adviser on safety is the Safety and Reliability Directorate at Risley.

The R \& D programme arises from consideration of four pressures upon the company as an MOD contractor, says Jones. First, it arises from Navy requirements for improvement in performance of future submarines, and their testing in prototype. Second, it arises from the need to apply innovations to the first of any new class of boat, or their "backfitting" to existing boats. Third, it arises from problems encountered at sea or in prototype operation. Fourth, it arises from new thinking about reactor design of safety criteria.

The company has been responsible for two major advances in the performance of the first British PWR, one already in fleet service since 1973, and the second scheduled to enter service in the near future. It is now developing the reactor for Britain's submarines in the $1990 \mathrm{~s}$ - a programme that owes much to the fourth consideration.

The focal point of reactor development in each case is the core, the very high precision assembly of fuel and control mechanisms that forms the heart of the NSSS. Even excluding the cost of the highly enriched uranium fuel itself, the core accounts for $23.5 \%$ of the price paid by the MOD for the reactor. But core design also intimately affects every other feature of PWR design.

\section{Increasing endurance}

The company's first development task, started in 1960, was for a more powerful, longer-lived core. Endurance rather than additional power is the over-riding objective of submarine reactor development, because fuel changing necessitates a major refit, including 
cutting through the pressure hull to access the reactor compartment. The new core first went critical in HMS Vulcan in 1968. It raised more power, and operated more than half as long again, as the first British-made core modelled on the US design. The new core entered service with the fleet in 1973. It can be backfitted to all UK submarines except Dreadnought.

In 1968 Rolls-Royce and Associates received its second major development contract from the Navy, for a reactor of still longer endurance between refuellings, combined with a new characteristic of fast-increasing importanceless noise and vibration. Power level, however, was to remain almost un- 2 changed. Concurrently, the company set up a team to investigate alternative reactor configurations, only to conclude that the Navy's specification could best be met with a third-generation British PWR. This core first went to power in HMS Vulcan last March. The Navy believes it will prove to have an energy output over its lifespan several times greater than the first British PWR.

Jones estimates that each of the steps in reactor development has been achieved for an outlay of $£ 6$ to $£ 7$ million, excluding the cost of prototype testing. The second-generation core achieved its advantages for a $19 \%$ increase in application cost over its predecessor; the third-generation core for between $16 \%$ and $30 \%$, depending upon whether one costs plant hardware to the core required or to the need for routine replacement. These figures are plainly indicative of a highly cost-effective defence research programme.

Research resources at Derby include Neptune, a zero energy research reactor begun in 1962, for physical tests on fuel modules. The fuel design has been considerably modified in detail for resistance against shock and the thermal stresses. The big gains in performance derive from the way it is made, assembled, cooled and controlled.

Hydrodynamic studies on cooling the core are carried out with perspex scale models of the pressure vessel and core, about one-third full scale, illuminated by lasers to reveal the flow patterns around the densely packed fuel. Larger rigs permit testing of full-scale components and sub-assemblies for heat transfer, noise, and so on.

The company has mounted a major development programme for nondestructive testing of critical reactor components such as the steel pressure vessel. This vessel has to be much closer to the dimensions of that of a large power-station PWR than its power output suggests to meet the Navy's specifications for military ro-

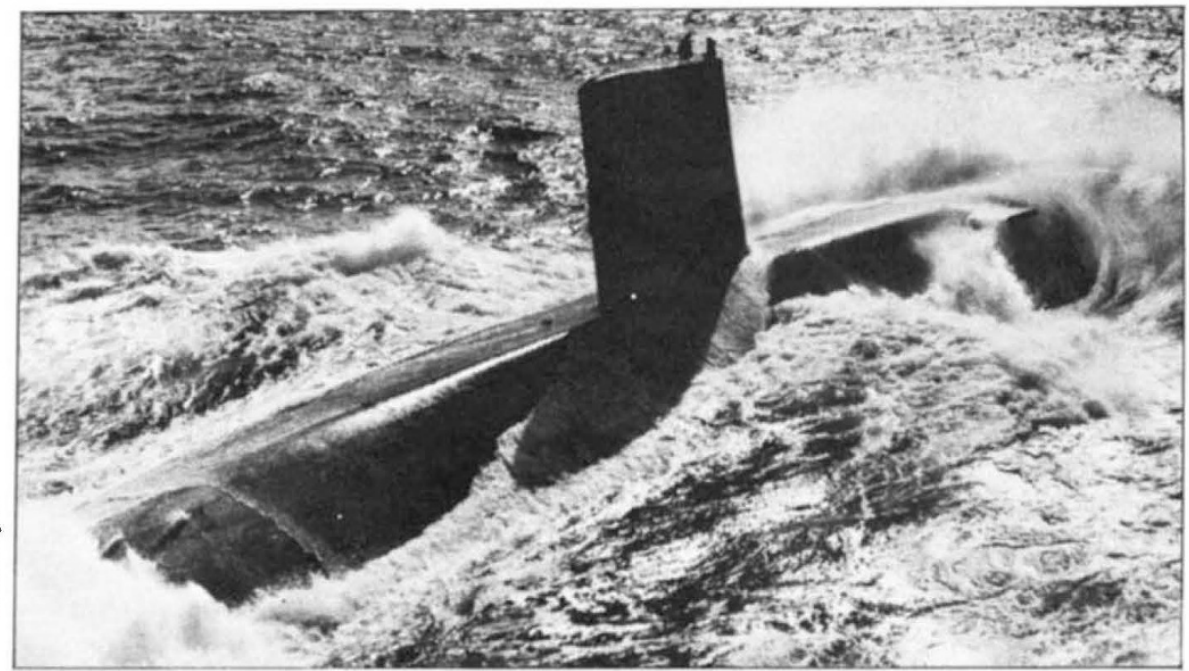

HMS Valiant surfacing off the west coast of Ireland

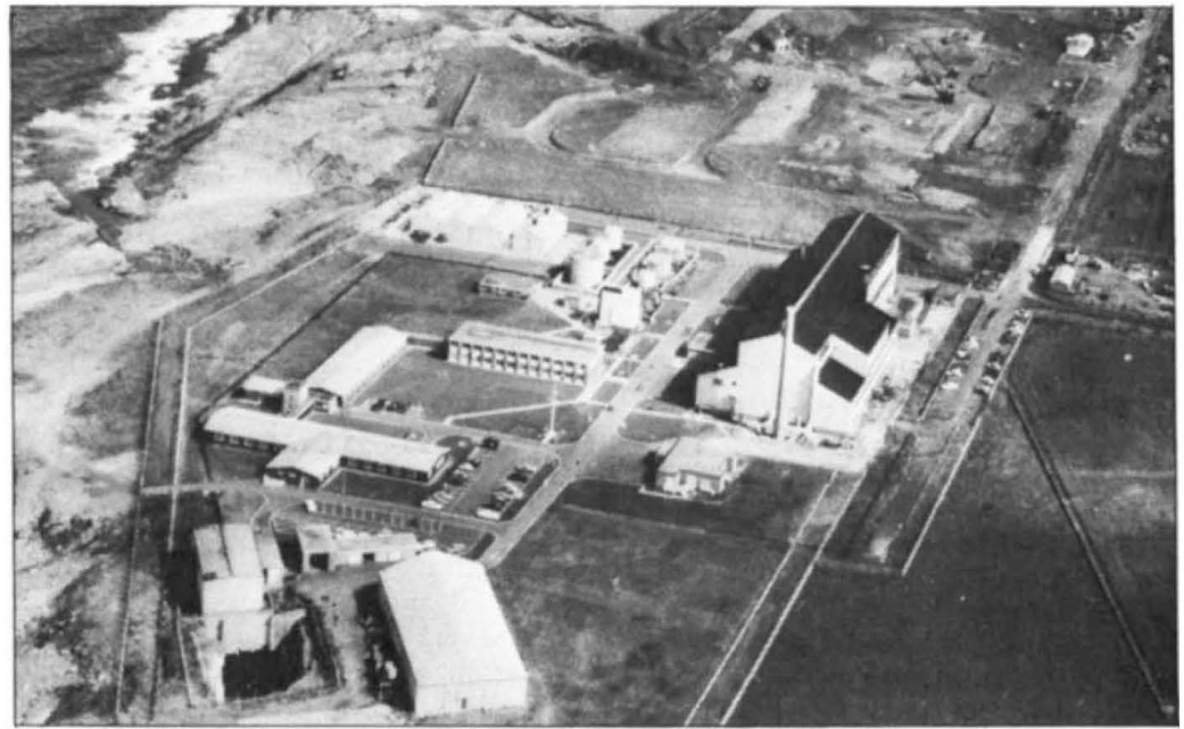

HMS Vulcan: the Royal Naval Test and Training Establishment, Dounreay, Scotland

bustness. Thus it is about two-fifths of the height, one-eighth of the weight and half the thickness of the vessel specified for a 1,300 MWe PWR-for one-fortieth of the rating. Studies have included $100 \%$ ultrasonic inspection of critical parts of the pressure vessel of the longest serving Navy reactor, at HMS Vulcan, by a scientist lowered into the vessel in a "lead bucket". The last word on the condition of this vessel will not be written, however, before 1982, when the prototype is dismantled and a post mortem held on such parts as the pressure vessel, which by then will have accumulated about 18 years of irradiation experience.

The opportunity to carve up this vessel will come as a result of a recent decision by the Navy to build a new shore test facility at HMS Vulcan. The Controller has placed a design and development contract with Rolls-Royce and Associates for the reactor it wants for service in the $1990 \mathrm{~s}$. The first step will be to test a new reactor built alongside the present facility, construction of which is scheduled to begin next year, for completion in the mid-1980s.

This will be another PWR. Enthusiasts among some US nuclear designers for lightweight, more powerful submarine reactors may misunderstand Navy requirements, says Jones. The Navy has no special interest in paring weight to the bone and needs to optimise the conflicting requirements of power and reactor noise. But the company is coy about the performance expected of the new PWR: "we'll end up with a safer, more reliable plant to meet a more stringent set of military objectives".

Nonetheless, there will be some big differences about the new test facility. For one thing, it will be the first PWR the company has designed "from scratch"-previously it has always been adapting the S5W Westinghouse reactor. For another, the plant will be laid out quite differently: the plant layout will be "exploded" for ease of access. Only the reactor itself will be contained in a representative section of pressure hull. 